\begin{tabular}{cc}
\hline International Journal of Engineering \&Technology, $7(3.12)(2018) 784-789$ \\
SPC & Website: www.sciencepubco.com/index.php/IJET \\
Research paper & International Journal of Engineering \& Technology \\
\hline
\end{tabular}

\title{
Influence of Engineered Microorganisms on Vermicomposting of Pre-processed Vegetable Waste
}

\author{
Senthilkumar Palaniappan ${ }^{1 *}$, Murugappan Alagappan ${ }^{2}$ \\ ${ }^{l}$ Government College of Engineering, Thanjavur \\ ${ }^{2}$ Annamalai University, Chidambaram \\ *Corresponding Author Email: ${ }^{1 *}$ plsphd15@ gmail.com, ${ }^{2}$ profam@gmail.com
}

\begin{abstract}
The low optimum level of vermi pile depth $(10 \mathrm{~cm}-15 \mathrm{~cm})$ warrants encroachment of large land area and consume more time in the vermicomposting process. In engineered vermicomposting, the acceleration of digestion of high volume of waste was done by eliminating the pre-composting and introducing pre-processing the waste. This process involves chopping, pulverizing, stocking, and drying the waste followed by injecting the engineered microorganisms (EM) at various depths in vermi bin during the vermicomposting process. Pre-processing and injection of EM enabled to increase the substrate depth by two-to-three-fold $(30 \mathrm{~cm})$. Experimentation was conducted in five vermi bins with same quantity of worms (100 gms of E. fetida in each bin), with different stock loads of EM (0.3ml, $0.4 \mathrm{ml}, 0.5 \mathrm{ml}, 0.6 \mathrm{ml}$ and $0.7 \mathrm{ml}$ ) named as Bin 1, Bin 2, Bin 3, Bin 4 and Bin 5 respectively. In parallel, a control (Bin C1) and conventional (Bin C2) vermi bin were also set up to compare the differences observed. The outcome of the study clearly showed that the bin loaded with $0.7 \mathrm{ml}$ EM (Bin 5) stock achieved high volume reduction (70\%). Moreover, the trail unit loaded with $0.5 \mathrm{ml}$ of EM stock (Bin 3) exhibited high biomass growth rate than its counter trail units.
\end{abstract}

Keywords: Vermicomposting, E. fetida, Effective Microorganism (EM).

\section{Introduction}

In recent years combating with solid waste becomes a difficult task around the world. Not only on Earth, even in space, solid waste (E-waste)creating a big problem by abraded satellites. Most of the developing nations produce huge amount of waste every year and this attributed to the change in the life style of the people. In India, implementation of solid waste management strategies began from the year $2 \mathrm{~K}$ and the MSW 2000 manual says that approximately 60 percent of waste volumes generated in India are organic in nature. This huge organic portion is not properly utilized in the energy sector. Recent studies show that organic waste fractions could be effectively utilized for manure production. Unfortunately, in India most of organic wastes are dumped in dump yard and left untreated, which leads to the production of greenhouse gases and other plague in the local environment [1]. The root cause for this practice is due to the imbalance state in waste production time to the waste treatment period.Plenty of research works have been carried out to convert the organic waste into energy. Out of many works few gave satisfactory results (Land fill, Composting, and Vermicomposting).

In sanitary landfill, wastes are digested in trench pattern and the energy extracted in the form of bio-gas by tapping it. This method requires huge land, cost and machine power. Composting and vermicomposting may be a more viable way, but the delay in the process again makes a hurdle in converting the waste into energy (manure) [2].Follow up researches in composting processes reduce

the time of waste digestion by $20 \%$ and the conclusion of the researches ends up in different directions in the waste digestion process [3].These researches aim to accelerate the digestion process by injecting "Effective Microorganism (EM)". EM (fig 1) solution developed by Dr. TeruoHiga, consists of a wide variety of active, favorable and non-pathogenic microorganisms produced through a natural process and not chemically fused or genetically engineered.
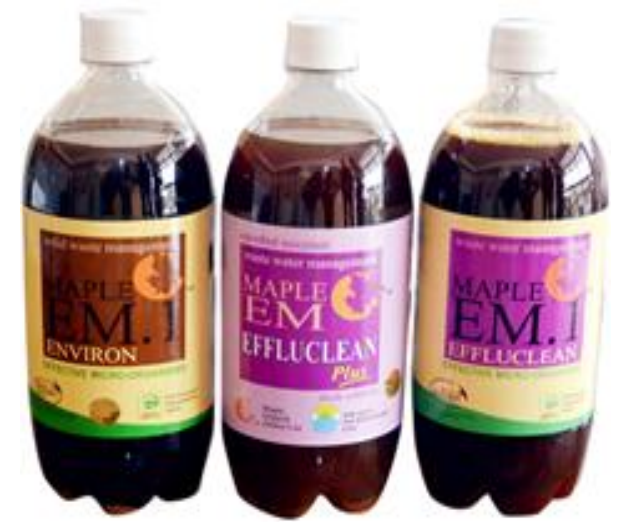

Fig. 1: Different forms of Effective Microorganism (EM) Solutions (Source: www.ecopro.in)

Microorganisms will exist certainly all over the environment from rock cracks to our interior body parts, but not all the microbes act friendly to the human. So it's our duty to isolate the good and evil and use them effectively. EM is one of the advanced isolation technique and used fororganic solid waste digestion process and it acts like a catalyst in the digestion process of waste digestion. It comes in a liquid form, which has no hostile effects on and is helpful to plants, animals, and humans. In general, EM act like a cleansing agent and anti-bacterial agent and protect us from 
harmful microorganism. The major constituting microbes in EM are Lactic Acid Bacteria (LAB), Yeast, and Phototrophic Bacteria (fig2a to 2c).

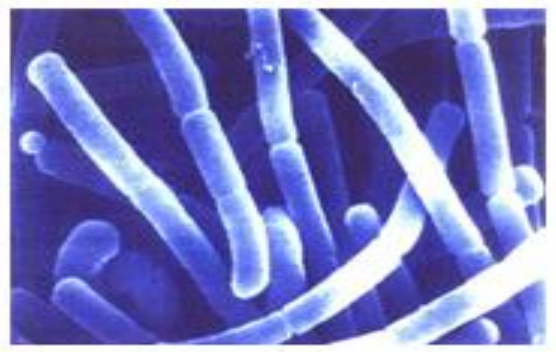

2(a) Lactic Acid Bacteria

Source: www.textbookofbacteriology.com

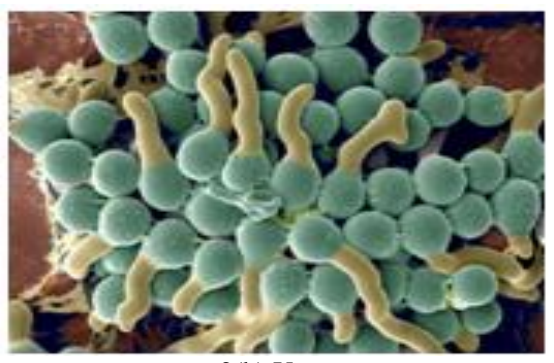

2(b) Yeast

Source: www.safetyanalyse.nl

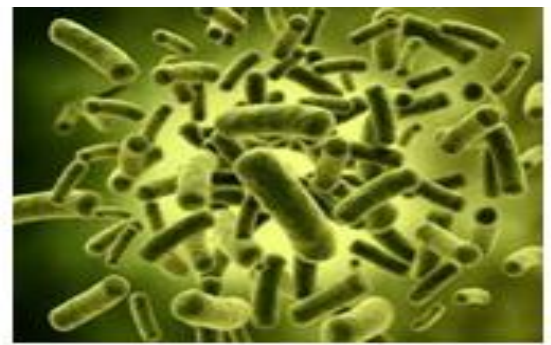

2(c) Phototrophic bacteria

Source: www.efficientmicrobes.co.za

Fig. 2: Microscopic view of Effective Microorganism (EM)

Lactic acid bacteria are, taxonomically, a general term for bacteria that alter huge quantities of sugars into lactic acid through lactic acid fermentation. Yeast was exposed by the Dutch merchant Antony Van Leeuwenhoek (1632-1723), who first discovered the world of microorganisms. In EM, yeast produces many biologically active agents such as amino acids and polysaccharides. Phototrophic bacteria or photosynthetic bacteria are a pre-historic kind of bacteria in presence from before the Earth had its present concentration of oxygen. As its name specifies, these bacteria consume lunar vitality to digest organic and inorganic matters. Many past researches reported EM plays an effective role in the composting process, but no study was reported in utilizing EM in vermicomposting process. Identifying this gap, present study aims to assess the effect of EM inoculum in vermicomposting of pre-processed vegetable waste by varying the EM load.

\section{Materials and Methods}

\subsection{Pre-Processing of Vegetable Waste}

Table 1: Proximate Analysis

\begin{tabular}{|c|c|c|c|c|}
\hline Nature of Vegetable Waste & $\begin{array}{c}\text { Bulk Density } \\
\left(\mathrm{kg} / \mathrm{m}^{3}\right)\end{array}$ & $\begin{array}{c}\text { Moisture Content } \\
(\%)\end{array}$ & $\begin{array}{c}\text { Size } \\
(\mathrm{mm})\end{array}$ & Volume reduction (\%) \\
\hline Raw waste & 91.00 & 61 & $100-300$ & 00 \\
\hline Chopped & 109.20 & 63 & $20-30$ & 20 \\
\hline Dried & 145.60 & 00 & 6 to 0.2 & 60 \\
\hline
\end{tabular}

The first step involved in waste processing is chopping (fig 3a). Initially the collected market wastes were screened for eliminating the inorganic and inert material. In order to ease the pulverizing process the waste was chopped to desired size $(20-30 \mathrm{~mm})$. Chopped wastes are having nominal size 20 to $30 \mathrm{~mm}$ converted into semi-solid form by pulverization. Pulverization is done mechanically and the main purpose of pulverization is to make the organic materials to achieve least size $(<0.1 \mathrm{~mm})$. Binding $(20 \%$ to waste volume) and bulking agents (5\% to waste volume) were added into the waste (pulverized form). The purpose of using bulking agents is to increase the proportion of air space or air voids in the waste mixture [4].Drying the waste is the final process, which removes the excess moisture content that causes foul smell during vermicomposting, and also remove volatile organic gases that upsets the Vermibin by producing unwanted gases. The waste mixture was allowed to dry under the Sun with an ambient temperature range between $33{ }^{\circ} \mathrm{C}$ to $40{ }^{\circ} \mathrm{C}$. The drying was done continuously for a maximum period of 4 to 5 days. This will reduce the volume to a maximum of 60 to 70 percent of its initial weight. Once peat is well dried, it is stored in a thick airtight plastic container for further process.

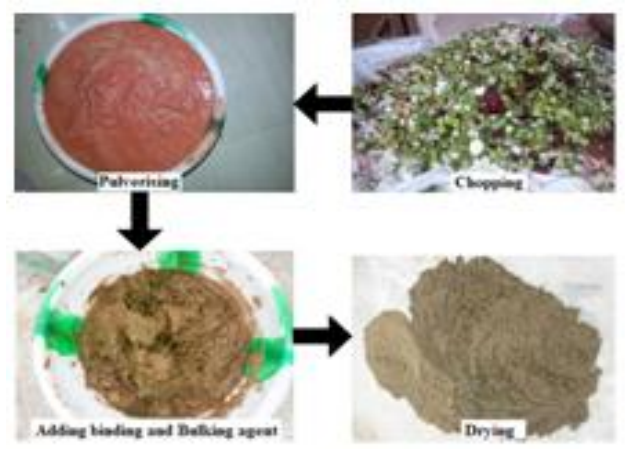

3(a) Pre-Processing of vegetable waste

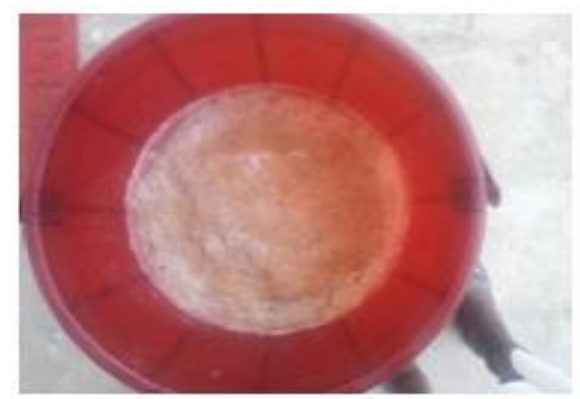

3(b) Activated EM stock.

Fig. 3: Process involved in Pre-processing of Vegetable Waste

\subsection{Characterization of the Raw and Pulverized Vegetable Waste}

Analysis of waste will provide necessary information about the physical and chemical characteristics of the waste. Moreover, it is essential in determining the efficiency of any treatment process. The analysis was divided in two phases 1 . Proximate analysis and 2. Ultimate analysis. All the analysis was done as recommended in "Manual on Municipal Solid Waste Management, Ist Edition, India (May 2000)". The analysis results are shown in table 1 and 2. 
Table 2: Ultimate analysis

\begin{tabular}{|c|c|c|c|c|c|}
\hline $\begin{array}{c}\text { Nature of Vegetable } \\
\text { Waste }\end{array}$ & $\begin{array}{c}\text { Organic Carbon 'C' } \\
(\mathrm{mg} / \mathrm{g})\end{array}$ & Nitrogen 'N'(mg/g) & Phosphorus 'P' (mg/g) & Potassium 'K' (mg/g) & C: N ratio \\
\hline Chopped & $\mathbf{3 8 . 6 2}$ & $\mathbf{1 . 1 2}$ & $\mathbf{4 . 8 5}$ & $\mathbf{2 8 . 9 6}$ \\
\hline Pulverized & 40.12 & $\mathbf{1 . 3 6}$ & $\mathbf{4 . 9 8}$ & $\mathbf{3 1 . 3 2}$ \\
\hline Dried & $\mathbf{4 6 . 3 5}$ & $\mathbf{1 . 6 3}$ & $\mathbf{5 . 3 2}$ & $\mathbf{3 3 . 2 6}$ \\
\hline
\end{tabular}

\subsection{EM Stock Preparations}

The inactive EM stock solution was bought from Maple Organic Tech (India) Limited and it was activated, then stocked. The activation processes began with mixing $1 \mathrm{~kg}$ of jaggery with 20 liters of potable drinking waste. To this mixture, one liter of EM stock solution was diluted. All this mixture was kept in a plastic container closed with a lid, for seven days. In order to expel the digested gases inside the plastic container, the lid was removed once in two days. The stock was ready to use after 10 days of the above said process. diameter are shown in fig 4 . In each bin, top $5 \mathrm{~cm}$ and bottom 5 $\mathrm{cm}$ were left as free board and drain bed respectively. Providing free board on top of the bin will prevents the escape of earthworm from the bins. The drain bed at the bottom of the bin was filled with pebbles of size $6 \mathrm{~mm}-8 \mathrm{~mm}$. An outlet was provided at the bottom of each vermin bin to collect the vermi wash as excess moisture if not drained will form a discomforting zone to worms by suffocating them. Out of seven bins, five were fed with EM stock on daily basis and bins were named as Bin 1, Bin 2, Bin 3, Bin 4 and Bin 5with $0.3 \mathrm{ml}, 0.4 \mathrm{ml}, 0.5 \mathrm{ml}, 0.6 \mathrm{ml}$ and $0.7 \mathrm{ml} \mathrm{EM}$ stock respectively. Bin $\mathrm{C} 1$ and $\mathrm{Bin} \mathrm{C} 2$ are conventional and control units.

\subsection{Fabrication of Vermi bin}

Seven vermi bins made of Poly vinyl chloride (PVC) pipes and each vermi bin having dimensions of $40 \mathrm{~cm}$ height and $15.24 \mathrm{~cm}$

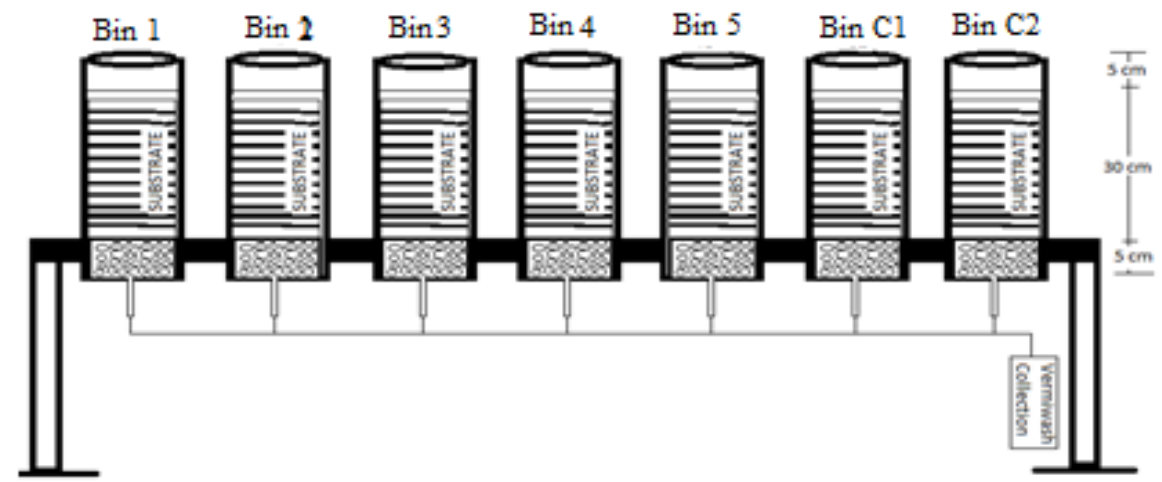

Fig. 4: Schematic representation of the vermi bins

\subsection{Inoculating the Earth Worms and Injecting the EM Stock}

All the bins (Bin 1, Bin 2, Bin 3, Bin 4, Bin 5 and Bin C1) filled with processed vegetable waste $(1 \mathrm{~kg}$ each) was run for 2 days before inoculating the earthworms. This will drained the presence of unwanted organic gases and stabilized the fluctuations of control parameters like moisture, temperature and $\mathrm{pH}$ in the substrate. On weight basis each bin was inoculated with worms (E.fetida) weighing $100 \pm 10 \mathrm{gm}$. In parallel, during moistening the vermi bin EM stock was injected with various loads starting from $0.3 \mathrm{ml}$ to $0.7 \mathrm{ml}$ in Bin 1 to Bin 5 respectively. A conventional unit and a control unit were also maintained for comparing the consolidation and volume reduction of substrate mass in the bins.

\subsection{Chemical Analysis}

Samples were collected every $5^{\text {th }}$ day from the bins for testing $\mathrm{pH}$ Total Organic Carbon (TOC), Total KjehldahlNitrogen (N) as per APHA (2005). Temperature, Moisture content and Electrical Conductivity (EC) are measured using WET sensor kit (WET-2$\mathrm{K} 1)$. All the collected data were reported in table 3 .

Table 3: Variations in Substrate depth, temperature and moisture content in various trial units

\begin{tabular}{|c|c|c|c|c|c|c|c|c|c|c|c|c|c|c|c|c|c|c|c|c|c|c|}
\hline \multirow[b]{2}{*}{$\begin{array}{c}\text { Da } \\
\mathbf{y}\end{array}$} & \multirow[b]{2}{*}{$\mathbf{T a}$} & \multicolumn{3}{|c|}{ BIN 1} & \multicolumn{3}{|c|}{ BIN 2} & \multicolumn{3}{|c|}{ BIN 3} & \multicolumn{3}{|c|}{ BIN 4} & \multicolumn{3}{|c|}{ BIN 5} & \multicolumn{3}{|c|}{ BIN C1 } & \multicolumn{3}{|c|}{ BIN C2 } \\
\hline & & d & $\mathbf{T}$ & $\begin{array}{l}\mathbf{M} \\
\mathbf{C}\end{array}$ & d & $\mathbf{T}$ & $\begin{array}{c}\text { M } \\
\text { C }\end{array}$ & d & $\mathbf{T}$ & $\begin{array}{l}\text { M } \\
\text { C }\end{array}$ & d & $\mathbf{T}$ & $\begin{array}{l}\text { M } \\
\mathbf{C}\end{array}$ & d & $\mathbf{T}$ & $\begin{array}{c}\text { M } \\
\text { C }\end{array}$ & d & $\mathbf{T}$ & $\begin{array}{c}\text { M } \\
\mathbf{C}\end{array}$ & d & $\mathbf{T}$ & $\begin{array}{c}\mathrm{M} \\
\mathrm{C}\end{array}$ \\
\hline 0 & $\begin{array}{c}31 . \\
2\end{array}$ & 30 & $\begin{array}{c}32 . \\
2\end{array}$ & 48 & 30 & 31.9 & 48 & 30 & $\begin{array}{c}32 . \\
6\end{array}$ & 48 & 30 & $\begin{array}{c}32 . \\
8\end{array}$ & 49 & 30 & 32 & 52 & 30 & $\begin{array}{c}32 . \\
3\end{array}$ & 48 & 30 & $\begin{array}{c}32 . \\
2\end{array}$ & 47 \\
\hline 5 & $\begin{array}{c}30 . \\
2\end{array}$ & 29 & $\begin{array}{c}31 . \\
3\end{array}$ & 47 & $\begin{array}{c}28 . \\
5\end{array}$ & $\begin{array}{c}31.6 \\
5\end{array}$ & 46 & $\begin{array}{c}28 . \\
4\end{array}$ & $\begin{array}{c}32 . \\
6\end{array}$ & 53 & $\begin{array}{c}28 . \\
2\end{array}$ & $\begin{array}{c}31 . \\
7\end{array}$ & 56 & $\begin{array}{c}27 . \\
5\end{array}$ & $\begin{array}{c}31 . \\
5\end{array}$ & 55 & 29 & $\begin{array}{c}31 . \\
9\end{array}$ & 47 & 29 & $\begin{array}{c}30 . \\
9\end{array}$ & 46 \\
\hline 10 & $\begin{array}{c}29 . \\
9\end{array}$ & $\begin{array}{c}27.9 \\
7\end{array}$ & $\begin{array}{c}31 . \\
4\end{array}$ & 48 & $\begin{array}{c}27 . \\
6\end{array}$ & $\begin{array}{c}31.4 \\
5\end{array}$ & 45 & $\begin{array}{c}26 . \\
8\end{array}$ & $\begin{array}{c}31 . \\
9\end{array}$ & 51 & $\begin{array}{c}26 . \\
5\end{array}$ & $\begin{array}{c}30 . \\
9\end{array}$ & 55 & $\begin{array}{c}25 . \\
6\end{array}$ & $\begin{array}{c}30 . \\
2\end{array}$ & 60 & $\begin{array}{c}28 . \\
4\end{array}$ & $\begin{array}{c}31 . \\
7\end{array}$ & 48 & $\begin{array}{c}28.3 \\
7\end{array}$ & $\begin{array}{c}30 . \\
4\end{array}$ & 47 \\
\hline 15 & 31 & 26.8 & $\begin{array}{c}33 . \\
7\end{array}$ & 46 & $\begin{array}{c}25 . \\
4\end{array}$ & $\begin{array}{c}32.1 \\
5\end{array}$ & 45 & $\begin{array}{c}25 . \\
2\end{array}$ & $\begin{array}{c}34 . \\
1\end{array}$ & 53 & $\begin{array}{c}24 . \\
5\end{array}$ & $\begin{array}{c}32 . \\
5\end{array}$ & 52 & $\begin{array}{c}23 . \\
7\end{array}$ & $\begin{array}{c}33 . \\
2\end{array}$ & 60 & $\begin{array}{c}27 . \\
5\end{array}$ & $\begin{array}{c}32 . \\
9\end{array}$ & 46 & $\begin{array}{c}28.4 \\
2\end{array}$ & $\begin{array}{c}30 . \\
8\end{array}$ & 44 \\
\hline 20 & $\begin{array}{c}29 . \\
6\end{array}$ & 24.5 & $\begin{array}{c}31 . \\
4\end{array}$ & 44 & $\begin{array}{c}22 . \\
3\end{array}$ & 31.5 & 44 & $\begin{array}{c}23 . \\
4\end{array}$ & $\begin{array}{c}31 . \\
1\end{array}$ & 52 & $\begin{array}{c}22 . \\
6\end{array}$ & $\begin{array}{c}32 . \\
3\end{array}$ & 57 & $\begin{array}{c}21 . \\
4\end{array}$ & $\begin{array}{c}31 . \\
7\end{array}$ & 59 & $\begin{array}{c}26 . \\
4\end{array}$ & $\begin{array}{c}31 . \\
6\end{array}$ & 44 & $\begin{array}{c}28.2 \\
4\end{array}$ & $\begin{array}{c}29 . \\
4\end{array}$ & 43 \\
\hline 25 & $\begin{array}{c}30 . \\
7\end{array}$ & 21.4 & $\begin{array}{c}30 . \\
9\end{array}$ & 46 & $\begin{array}{c}19 . \\
5\end{array}$ & 32.9 & 43 & $\begin{array}{c}21 . \\
7\end{array}$ & $\begin{array}{c}32 . \\
7\end{array}$ & 53 & $\begin{array}{c}20 . \\
5\end{array}$ & $\begin{array}{c}32 . \\
9\end{array}$ & 56 & $\begin{array}{c}19 . \\
6\end{array}$ & $\begin{array}{c}31 . \\
7\end{array}$ & 58 & $\begin{array}{c}24 . \\
7\end{array}$ & $\begin{array}{c}31 . \\
9\end{array}$ & 46 & $\begin{array}{c}27.9 \\
5\end{array}$ & $\begin{array}{c}30 . \\
2\end{array}$ & 45 \\
\hline 30 & $\begin{array}{c}31 . \\
2\end{array}$ & 18.6 & $\begin{array}{c}31 . \\
7\end{array}$ & 48 & $\begin{array}{c}17 . \\
5\end{array}$ & 32.2 & 49 & $\begin{array}{c}18 . \\
9\end{array}$ & $\begin{array}{c}33 . \\
6\end{array}$ & 55 & $\begin{array}{c}17 . \\
8\end{array}$ & $\begin{array}{c}33 . \\
9\end{array}$ & 56 & $\begin{array}{c}17 . \\
6\end{array}$ & $\begin{array}{c}33 . \\
4\end{array}$ & 59 & $\begin{array}{c}22 . \\
8\end{array}$ & $\begin{array}{c}32 . \\
5\end{array}$ & 48 & $\begin{array}{c}27.6 \\
5\end{array}$ & $\begin{array}{c}30 . \\
5\end{array}$ & 46 \\
\hline 40 & 31. & 16.5 & 31. & 46 & 13. & 32.6 & 48 & 12. & 33. & 52 & 12. & 34. & 53 & 12. & 34. & 58 & 19. & 31. & 46 & 26.6 & 31. & 44 \\
\hline
\end{tabular}




\begin{tabular}{|c|c|c|c|c|c|c|c|c|c|c|c|c|c|c|c|c|c|c|c|c|c|c|}
\hline & 4 & & 9 & & 6 & 5 & & 2 & 9 & & 7 & 9 & & 9 & 6 & & 5 & 6 & & 8 & 8 & \\
\hline 45 & $\begin{array}{c}30 . \\
4\end{array}$ & 15.5 & $\begin{array}{c}31 . \\
5\end{array}$ & 43 & $\begin{array}{c}12 . \\
4\end{array}$ & 31.7 & 48 & $\begin{array}{c}11 . \\
8\end{array}$ & $\begin{array}{c}31 . \\
4\end{array}$ & 54 & $\begin{array}{c}10 . \\
4\end{array}$ & $\begin{array}{c}31 . \\
9\end{array}$ & 54 & 9.8 & $\begin{array}{c}31 . \\
2\end{array}$ & 59 & $\begin{array}{c}17 . \\
9\end{array}$ & $\begin{array}{c}31 . \\
5\end{array}$ & 42 & $\begin{array}{c}26.1 \\
5\end{array}$ & $\begin{array}{c}30 . \\
2\end{array}$ & 45 \\
\hline 50 & $\begin{array}{c}29 . \\
9\end{array}$ & 14.4 & $\begin{array}{c}29 . \\
3\end{array}$ & 45 & $\begin{array}{c}11 . \\
5\end{array}$ & 30.9 & 47 & $\begin{array}{c}10 . \\
4\end{array}$ & $\begin{array}{c}30 . \\
7\end{array}$ & 53 & 8.5 & $\begin{array}{c}30 . \\
6\end{array}$ & 55 & 7.5 & $\begin{array}{c}30 . \\
9\end{array}$ & 58 & $\begin{array}{c}16 . \\
5\end{array}$ & $\begin{array}{c}29 . \\
3\end{array}$ & 43 & $\begin{array}{c}25.7 \\
5\end{array}$ & $\begin{array}{c}30 . \\
4\end{array}$ & 46 \\
\hline
\end{tabular}

\section{Results and Discussion}

The outcome of the experimental study shows a significant variation in various parameters and they are reported as follows. To start with the temperature profile, it shows high variations in all the Vermibin (fig 5) expect the control bin. Out of all the bins, bins loaded with microbial inoculants shows persistent rise in temperature. Bin 5 augmented with $0.7 \mathrm{ml}$ of microbial load achieved peak by $3.5^{\circ} \mathrm{C}$, compared to ambient temperature. And more similar patterns were recorded in Bin 3 and 4, with a rise of $3.1^{\circ} \mathrm{C}$ and $3.3^{\circ} \mathrm{C}$ respectively. The rise in temperature indicates the involvement of microbes in the waste disintegration process as microbes convert organic waste into $\mathrm{CO} 2$ and humic substance and release heat as by-product. In order to maintain the optimum temperature (less than $32^{\circ} \mathrm{C}$ ), Bin 3 , Bin 4 , andBin 5 were periodically moistened and that reflected in high moisture content in these bins (fig 6) and the moisture in all these 3 Bins were in the range between 50 and 55 percent. Even though vermicomposting is non-thermophilic process [5] the presence of glucoproteins and small glucosidic and protein molecules in the organic waste provide a good source of energy for the inoculated microbes and provides an effective sustainable environment for germination of new cells. This could be one among the reasons for the rise in the temperature profile. Other than this, the rise in bin temperature may also be due to consolidation of substrate mass after the first week of experimentation. The temperature in all the bins comes to a saturation level at the end 50th day. This may be due to reduction of substrate mass.

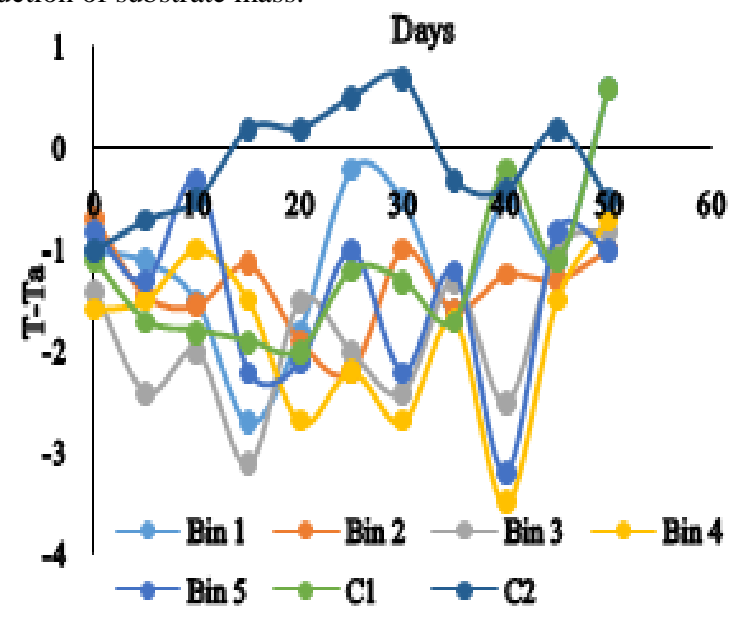

Fig. 5: Variations in Temperature

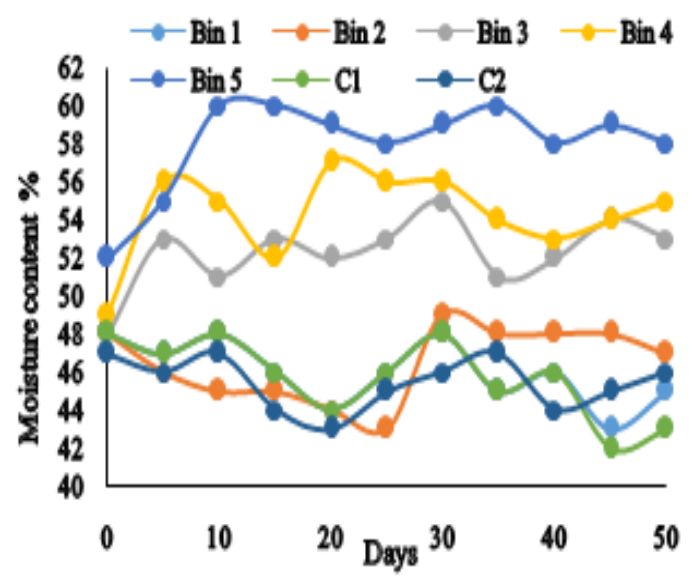

Fig. 6: Variations in Moisture Content
As pre-processed waste augments ready source of nutrients it has largely increased the microbial activity which in turn enables them to contribute enzymes to the digestive processes. The microbial inoculant enhance the activity of cellulose, which produce alkaline phosphatases to a greater extent. Moreover, the yeast population in the EM increases the fermentation activity in waste and as a byproduct it produces more organic acids and other gases. This was emphasized by the fall of $\mathrm{pH}$ in $\mathrm{Bin} 4$ and 5 , as this to bins aided with high EM stock. In addition the early breakdown of bigger fractions of organic mixtures, such as ligno-cellulose, are tainted to humic substances [6] and this is expected due high population density of microbes, which may be one among the reasons in high variation of $\mathrm{pH}$
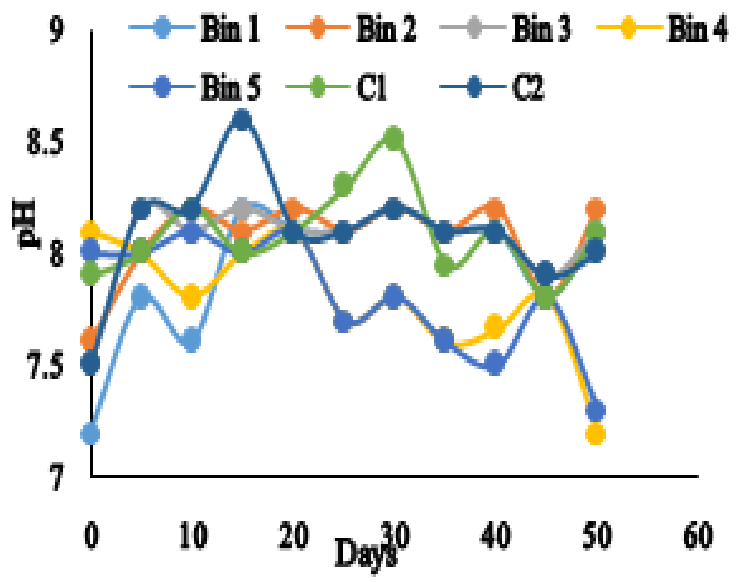

Fig. 7: Variations in $\mathrm{pH}$

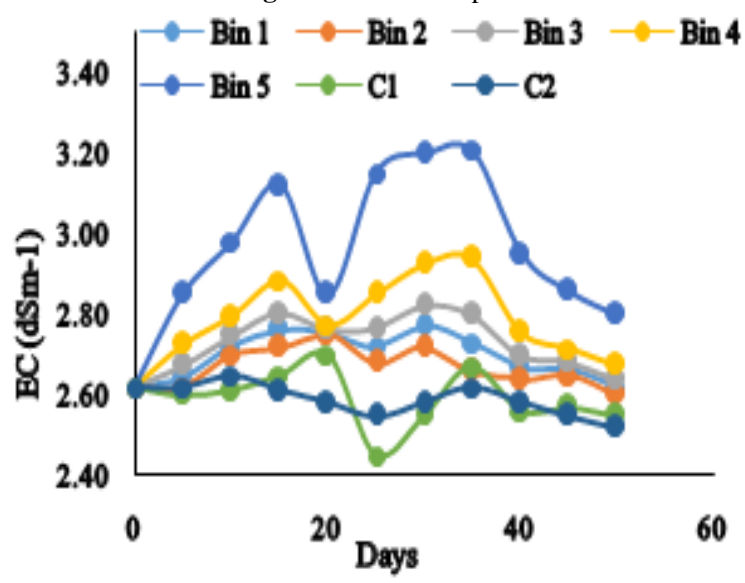

Fig. 8: Variations in EC

The variations of $\mathrm{pH}$ (fig 7 ) in all the other bins depicted similar pattern and it falls in the range of 7.5 to 8 . Electrical conductivity (EC) shows the consistent rising trend in the bins loaded with microbial inoculants. This may due to two reasons (1) enzymes released from the skin of worms due to the respiratory activity of it (2) release of mineral salts and ammonium ions through the decomposition of organic matter due to the metabolic activities of microbes [7]. EC in bin 5 shows enormous variations and rising trend throughout the experimentation period. Apart from Bin 5, Bin 4 and Bin 3 show the significant rising trends, but not as similar as in Bin 5. This may be due to the precipitation of mineral salts and volatilization of ammonia [8]. On the 50th day of experimentation, EC in all the bins came to saturation limit and it stood at \pm 2.7 ( $\mathrm{dSm}$-1). It is a known fact that Carbon plays an effective role for all living organisms. 


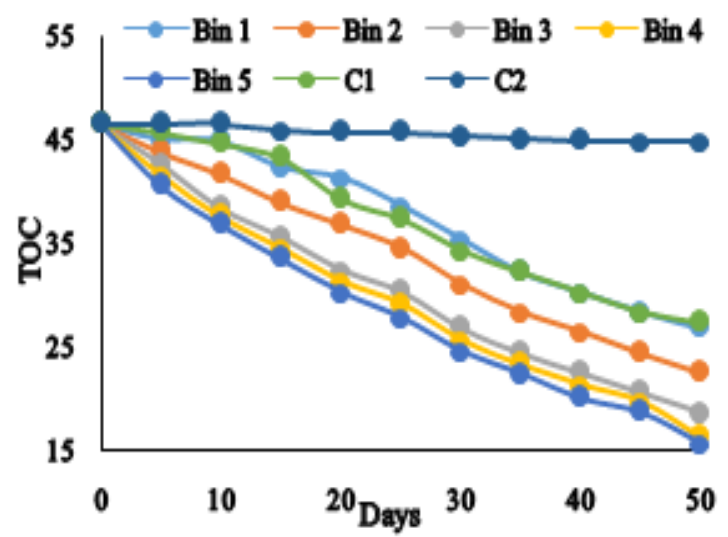

Fig. 9: Variations in Organic carbon

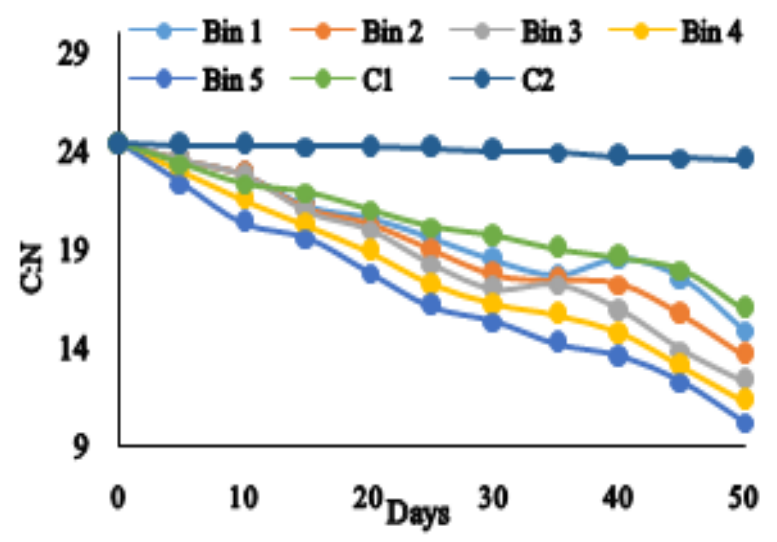

Fig. 10: Variations in C:N ratio

The pre-processed vegetable waste blended with the optimum amount of cow dung provides a suitable environment and food source for both worms and microbes. This is well witnessed by the fall of Total Organic Carbon (TOC) in all the bins (fig 9). In spite of the fall of TOC levels in all the bins, bin 5 shows the high percentage reduction of TOC (67\%), followed by bin 4 and bin 3 with the level of $65 \%$ and $60 \%$ respectively. The fall in the carbon level may be associated with the carbon intake by photo bacteria other microbes in the bin and followed by the role of worm digestion activity. Worms consume more carbon source and this was evident by [9], who reported $20-40 \%$ loss of organic carbon in the form of $\mathrm{CO} 2$ during vermicomposting. Further, [5] reported that the body fluid and excreta secreted by worms (e.g., mucus, high concentration of organic matter, ammonium and urea) promote microbial growth in vermicomposting, which may also contribute in the reduction of carbon level. The TOC level stood between 22, 26, and 27 in Bin 3, Bin 1 and Bin $\mathrm{C} 1$ respectively. The drop in TOC reduction level in these bins may be due to low microbial population. The level of C:N ratio(fig 9) shows the maturity level of organic waste [10]. The level of C:N ratio shows the maturity level of organic waste (fig10).The ratio gets down with respect to ingesting of organic carbon or loss by inhalation through microbes and it may also be due to the addition of nitrogenous excretory matters during rotting process [11]. Since $\mathrm{C}: \mathrm{N}$ ratio is a mere reflection of TOC reduction levels, bin 5 holds with high drop of $\mathrm{C}: \mathrm{N}$ levels in the bin and it stood at 10.25 at the end. And it was 11.3, 12.35, 13.62, 14.89 and 16 in Bin 4, Bin 3, Bin 2, Bin 1 and Bin $\mathrm{C} 1$ respectively. The loss in $\mathrm{C} / \mathrm{N}$ ratio may also due to the increase of nitrogen content by mineralisation of the organic matter and in addition with nitrogenous waste generated by earthworms [12].

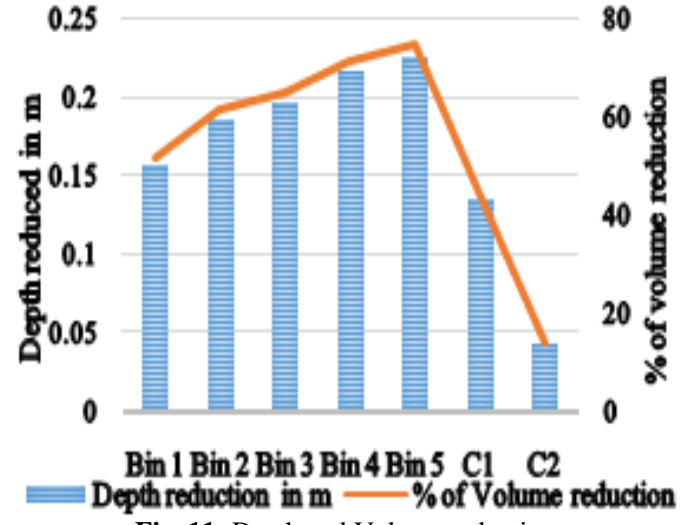

Fig. 11: Depth and Volume reduction

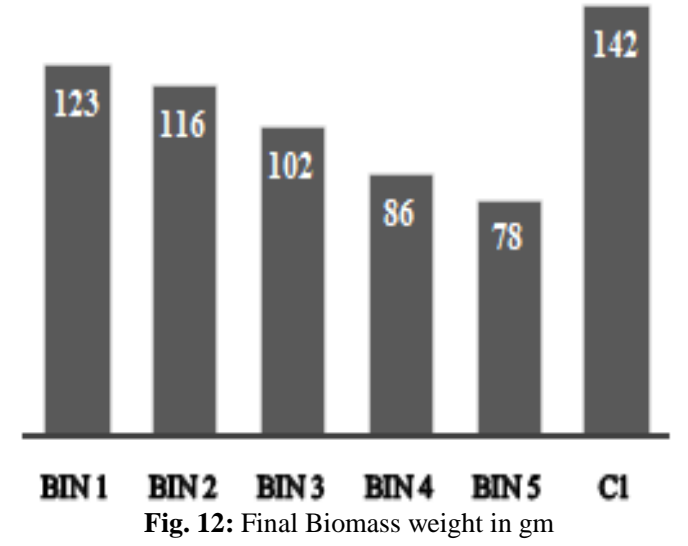

Fig 11 shows the depth and volume reduction of waste in all the bins. The core aim of this experimental study was well emphasized by the volume reduction achieved in Bin 5, as this bin records a high volume reduction of $75 \%$ followed byBin 4 and Bin 3 with 71 and $65 \%$. Bin 2 and Bin 1 records 61 and $52 \%$ during the experimentation. It was well witnessed that augmenting EM stock in vermicomposting will reduce high volume reduction when compared to plane vermicomposting, since Bin $\mathrm{C} 1$ records only $45 \%$ of volume reduction. As discussed earlier, the reduction of waste load is mainly due to the combined vandalization waste by worms and microbes [13]. Any have identifying the optimum dose of EM stock is not possible because the disintegration of waste is directly proportional to the microbial and worm population. But aiding too much of microbial load will reduce the growth of biomass due to the lag of free available carbon source. Since worm's motility falls less than $10 \mathrm{~cm}$ depth [14], the inoculants flows beneath this depth utilize more carbon source for cell stylization and metabolic process. This was evident in fig 12, as the final earthworm biomass growth was reduced to $78 \mathrm{gm}$ and it was $100 \mathrm{gm}$ at the beginning of the experiment. More similar fall patterns of earth worm biomass weight recorded in bin 4 (86 $\mathrm{gm})$ and $3(102 \mathrm{gm})$, while it was around $140 \mathrm{gm}$ in the bin $\mathrm{C} 1$ with no EM inoculant.

\section{Conclusions}

The study expels the scope of using or augmenting microbial inoculants in vermicomposting of pre-processed vegetable waste. The final outcome of the study shows that utilizing combined amount of EM stock ( 0.3 to $0.4 \mathrm{ml}$ per day) will accelerate the digestion of organic waste to a reasonable extent. But the microbial population exhausts more carbon source which makes a negative reflection on worm's biomass growth. Hence it is concluded that augmenting EM stock in vermicomposting is beneficial in terms of volume reduction of more waste in less duration than the time it took in plain vermicomposting. 


\section{Acknowledgments}

The authors wish to thank the Environmental laboratory of Civil Engineering department, Annamalai University,

Chidambaram, India for rendering all the facilities to complete this study a great success.

\section{References}

[1] R.K. Bastian, J.A. Ryan, 1986. Design and management of successful land application system. In: Utilization Treatment and Disposal of Waste on Land. Soil Science Society of America, Madison, WI, USA, pp. 217-229.

[2] Tara Crescent., 2003. Vermicomposting. Development Alternatives (DA) Sustainable Livelihoods. (http://www.dainet.org/livelihoods/default.htm)

[3] A. Martin,\&P. Lavelle, 1992. Effect of soil organic matter quality on its assimilation by Millsoniaanomala, a tropical geophagous earthworm. Soil Biol. Biochemis. 24(12), 1535-1538.

[4] S. Surthar and Sing., 2007. Vermicomposting of domestic waste by using two epigeic earthworms (Perionyxexcavatus and Perionyxsansibaricus). International Journal of Environmental Science \& Technology, December 2008, Volume 5, Issue 1, pp 99106.

[5] S. Suthar, 2008. Bioconversion of post-harvest crop residues and cattle shed manure into value-added products using earthworms EudriluseugeniaeKinberg. Ecol. Eng. 32, 206-214.

[6] L.S. Ranganathan., 2006. Vermibiotechnology- From soil Health to Human health. Agrobios (India), ISBN No: 81-7754-294-X

[7] G. SenthilKumar, PL. Senthilkumar, A. Murugappan., 2011. Investigation on application of catalytic substance for augmenting worm growth rate in vermicomposting. JIPHE Vol: 2011-12, 15-19.

[8] S.V. Bolta, R. Mihelic, F. Lobnik, D. Lestan, 2003. Microbial community structure during composting with and without mass inoculate. Compost Science and Utilization 11, 6-15.

[9] J.M.C. Wong, G.X. Li, \&M.H. Wong,1997. Feasibility of using ash residues composting materials for sewage sludge. Environ.Technol. 18(5), 563-568

[10] R. Hartenstein, \&F. Hartenstein, 1981. Physico-Chemical changes effected in activated sludge by the earthworm (Eiseniafoetida). J.Environ. Quality 10(3), 377-382.

[11] Y. Araujo, F.J. Luizão, \&E. Barros, 2004. Effect of earthworm addition on soil nitrogen availability, microbial biomass and litter decomposition in mesocosms Biol. Fert. Soils 39 (2), 146-152.

[12] PL. Senthilkumar \&T. Kavimani, 2012. Investigation in application of synthetic nutrients for augmenting worm growth rate in vermicomposting. Journal of Urban and Environmental Engineering 2012, v.6, n.1, p.30-35.

[13] Kaviraj and S. Sharma., 2003. Municipal Solid Waste management through Vermicomposting employing exotic and local species of earthworm. Biores. Technol. 90(2), 169-173.

[14] N B Sing, A K Khare, D S Bhargava and S Bhattacharys., 2004. Effect of substrate depth on vermicomposting. IE (I) Journal - EN Vol 85, 16-21. 